CASE REPORT

\title{
A new FSH $\beta$ mutation in a 29-year-old woman with primary amenorrhea and isolated FSH deficiency: functional characterization and ovarian response to human recombinant FSH
}

\author{
Marie-Laure Kottler, Yen-Yin $\mathrm{Chou}^{2,3}$, Olivier Chabre ${ }^{1}$, Nicolas Richard, Camille Polge ${ }^{1}$, Sylvie Brailly-Tabard ${ }^{4,5,7}$, \\ Philippe Chanson $^{4,5,6}$, Anne Guiochon-Mantel ${ }^{4,5,7}$, Ilpo Huhtaniemi ${ }^{2}$ and Jacques Young ${ }^{4,5,6}$ \\ Unité de Formation et de Recherche de Médecine Centre Hospitalier Universitaire, Département Génétique et Reproduction, Université de Caen \\ Basse-Normandie, F-14032 Caen, France, ${ }^{1}$ Service d'Endocrinologie, Université et CHU Grenoble, Grenoble, F-38000 France, ${ }^{2}$ Department of \\ Reproductive Biology, Imperial College London, Hammersmith Campus, Du Cane Road, London W12 ONN, UK, ${ }^{3}$ Institute of Clinical Medicine, National \\ Cheng Kung University Medical College and Hospital, Tainan, Taiwan, ROC, ${ }^{4}$ Faculté de Médecine Paris-Sud, Université Paris-Sud 11, Le Kremlin Bicêtre \\ F-94276, France, ${ }^{5}$ INSERM UMR-S693, Le Kremlin Bicêtre F-94276, France, ${ }^{6}$ Assistance Publique-Hôpitaux de Paris, Hôpital de Bicêtre, Service \\ d'Endocrinologie et des Maladies de la Reproduction, 78, Rue du Général Leclerc, Le Kremlin Bicêtre F-94275, France and ${ }^{7}$ Laboratoire de Génétique \\ Moléculaire, Pharmacogénétique et Hormonologie, Le Kremlin Bicêtre F-94275, France
}

(Correspondence should be addressed to J Young at Assistance Publique-Hôpitaux de Paris, Hôpital de Bicêtre, Service d'Endocrinologie et des Maladies de la Reproduction; Email: jacques.young@bct.aphp.fr)

(M-L Kottler and Y-Y Chou contributed equally to this work; I Huhtaniemi and J Young contributed equally to this work)

\begin{abstract}
Context: Mutations of the FSH $\beta$ gene, causing in women isolated FSH deficiency and hypogonadism, are very rare and only a few have been described.

Objective: To describe the phenotype and response to recombinant human (rh) FSH of a female patient with a novel homozygous loss-of-function mutation of $F S H \beta$, and to characterize in vitro the molecular mechanisms responsible for the FSH inactivation.

Patient: A 29-year-old woman with primary amenorrhea and impaired pubertal development associated with isolated FSH deficiency.

Methods and results: Sequencing of the FSH $\beta$ gene revealed a homozygous 1 bp (G) deletion at codon 79 (c.289delG) of exon 3 which produced a frameshift at codon 79 (A79fs108X) and a premature stop codon at codon 109. The wild-type and mutant FSH $\beta$ cDNAs inserted into expression vector were cotransfected into Chinese hamster ovary cells with the $\alpha$-subunit. Wild-type FSH was readily detectable in culture medium, whereas no mutant FSH was detectable by either immunoassay or in vitro bioassay. Mutant FSH $\beta$ protein could not be detected in western blot.

In response to a 15-day treatment with rhFSH, sonography revealed multifollicular development in the ovaries. Circulating levels of estradiol and inhibin B were dramatically increased, whereas antiMullerian hormone decreased. Serum LH first decreased and then increased, inducing multiovulation associated with supraphysiologic progesterone and inhibin A levels.

Conclusion: A novel FSH $\beta$ mutation was detected in a hypogonadal woman. rhFSH was effective in ovulation induction in the patient but with signs of ovarian hyperstimulation. The high pretreatment $\mathrm{LH}$ levels could contribute to this excessive ovarian response to rhFSH.
\end{abstract}

European Journal of Endocrinology 162 633-641

\section{Introduction}

The pituitary gonadotropins, LH and FSH regulate the production of sex steroids necessary for the pubertal development and fertility. Inherited genetic defects that cause hypogonadism in females have been identified at multiple levels of the hypothalamic-pituitary-gonadal axis, including GnRH, its receptor, GPR54/KISS1R, TAC3/TACR3, gonadotropin subunits, genes involved in autosomal Kallmann syndrome and CHARGE syndrome, and gonadotropin receptors (1-17). Inactivating mutations in the $F S H \beta$ gene have been found to date in five women with delayed puberty and isolated FSH deficiency $(8,10,11,16-19)$. These very rare natural mutations in the $F S H \beta$ subunit gene are nevertheless interesting models to elucidate several aspects of the gonadotropin-dependent ovarian physiology and physiopathology. In this study, we report and characterize in vitro a novel FSH $\beta$ mutation and demonstrate that the mutant $F S H \beta$ displays impaired 
immunoreactivity and bioactivity in vitro and failure of expression at protein level, confirming that this newly described mutation causes the phenotype of isolated FSH deficiency. We also had the opportunity to study in detail the pituitary and ovarian responses in this patient to sustained recombinant human (rh) FSH administration.

\section{Case report}

The proband (Subject II-1 in Fig. 1A), a Caucasian woman of Spanish origin, was referred to our department at the age of 29 years for primary amenorrhea. She had undergone incomplete pubarche at the age of 18, but had no evidence of thelarche. At 29 years, she was $165 \mathrm{~cm}$ tall, with a bone age of 16 years. Breast development was Tanner stage 2 and pubic hair $\mathrm{P} 4$, and there was no hirsutism, acne or seborrhea. There was no family history of delayed puberty or infertility, but her parents were first cousins (Fig. 1A). The patient's karyotype was 46, XX. Initial endocrinological evaluation (Table 1) showed undetectable basal and GnRH-stimulated (100 $\mu$ g i.v.) levels of serum FSH, measured with three different assays. In contrast, serum LH was high and rose after GnRH stimulation from 49 to $170 \mathrm{IU} / \mathrm{l}$ at $30 \mathrm{~min}$, and to $130 \mathrm{IU} / \mathrm{l}$ at $60 \mathrm{~min}$. Serum estradiol $\left(\mathrm{E}_{2}\right)$ was very low but testosterone, androstenedione, and DHEAS levels were within the normal range for age. Inhibin $B$ was not detectable, but serum anti-Mullerian hormone $(\mathrm{AMH})$ was in the normal range for age. Prolactin $(8.9 \mu \mathrm{g} / \mathrm{l})$, thyrotropin $(2.2 \mathrm{U} / \mathrm{l}$; normal $0.5-4.5 \mathrm{U} / \mathrm{l})$, and free thyroxine levels were normal. Ultrasound examination revealed a small uterus (volume $5.6 \mathrm{~cm}^{3}$ ) and two small (1.0 and $1.6 \mathrm{ml}$ ) ovaries with few follicles of $<3 \mathrm{~mm}$ diameter. Bone mineral density of the lumbar spine was very low $\left(0.71 \mathrm{~g} / \mathrm{cm}^{3}\right.$; Z score -2.6$)$. Magnetic resonance imaging of the brain and pituitary gland revealed no abnormalities.

Because the patient desired to have her fertility assessed, rhFSH treatment was proposed.

\section{Methods}

\section{Hormone assays}

FSH was measured by three different immunoassays as previously reported $(1,20,21)$. LH, inhibin B, and AMH were measured with sensitive immunoradiometric or ELISA assays as previously described (22). Plasma $\mathrm{E}_{2}$, progesterone, testosterone, androstenedione, and DHEAS were measured by RIA as reported elsewhere (23). Serum inhibin A was measured as reported before (24).
A

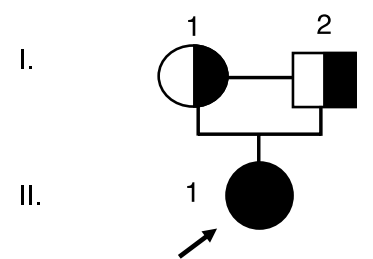

B

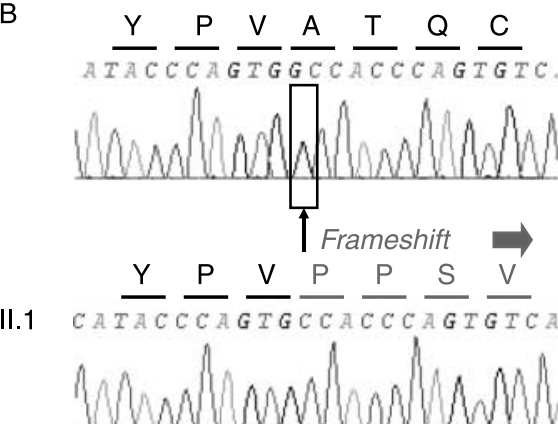

C

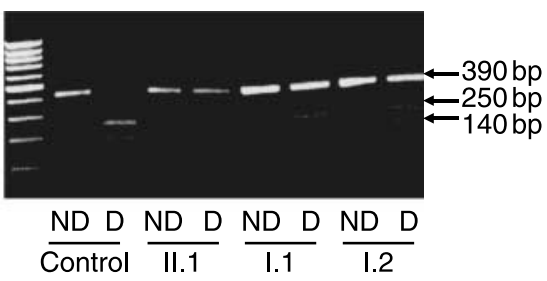

\section{Wild-type}

c.289delG

Homozygous

Figure 1 Family pedigree and $F S H \beta$ new mutation. (A) Family pedigree. Black symbol indicates the affected patient. Half-shaded symbols indicate unaffected heterozygotes. Circles represent females and square male family members. The arrow indicates the propositus. (B) Result of automatic sequencing of exon 3 of $F S H \beta$ of the propositus in comparison to the respective wild-type sequence. The deleted guanine at position c.289 is indicated by an arrow on the wild-type sequence. In-frame amino acids are indicated above each sequence. (C) RFLP analysis of the mutated $F S H \beta$ sequence. The deletion (c.289delG) eliminates a $\mathrm{Msc} /$ restriction site. PCR-amplified fragment of exon 3 in the absence of $\mathrm{Mscl}$ (ND, not digested). After digestion of a PCR-amplified fragment of exon 3, normal PCR product is resolved into two bands of 140 and $250 \mathrm{bp}$ (D, digested). As expected, cleavage of the PCR product was not observed in the proband (individual II.1). We observed three bands after digestion of PCR products of the mother (subject I.1.) and the father (subject I.2.), according to their heterozygous status. 
Table 1 Initial hormonal evaluation of the patient.

\begin{tabular}{lcc}
\hline & Basal & Normal range $^{\mathrm{a}}$ \\
\hline FSH IEA (IU/l) & $<0.4^{\mathrm{b}}$ & $2.8-7.1$ \\
FSH IRMA $(\mathrm{IU} / \mathrm{l})$ & $<0.05^{\mathrm{b}}$ & $3.2-8$ \\
FSH RIA $(\mathrm{IU} / \mathrm{l})$ & $<0.1^{\mathrm{b}}$ & $2.9-7.8$ \\
LH $(\mathrm{IU} / \mathrm{l})$ & $46-59^{\mathrm{c}}$ & $2.8-6.9$ \\
$\alpha$-Subunit $(\mu \mathrm{g} / \mathrm{l})$ & 0.85 & $0.2-0.6$ \\
Estradiol $(\mathrm{ng} / \mathrm{l})$ & 7 & $28-76$ \\
Progesterone $(\mu \mathrm{g} / \mathrm{l})$ & $<0.4$ & $<0.4$ \\
Testosterone $(\mu \mathrm{g} / \mathrm{l})$ & 0.4 & $0.2-0.6$ \\
Androstenedione $(\mu \mathrm{g} / \mathrm{l})$ & 1.5 & $0.8-1.6$ \\
17-Hydroxyprogesterone $(\mu \mathrm{g} / \mathrm{l})$ & 0.32 & $0.2-0.7$ \\
DHEAS $(\mu \mathrm{g} / \mathrm{l})$ & 1887 & $400-3560$ \\
Inhibin B $(\mathrm{ng} / \mathrm{l})$ & $<10^{\mathrm{b}}$ & $60-125$ \\
Inhibin A $(\mathrm{ng} / \mathrm{l})$ & $<10^{\mathrm{b}}$ & $<10$ \\
AMH $(\mathrm{pmol} / \mathrm{l})$ & 31 & $5-52$ \\
Prolactin $(\mu \mathrm{g} / \mathrm{l})$ & 8.5 & $10-20$ \\
\hline
\end{tabular}

Conversion to SI units: prolactin: $\mu \mathrm{g} / \mathrm{I} \times 27=\mathrm{mUI} / \mathrm{l}$; DHEAS: $\mu \mathrm{g} / \mathrm{ml} \times 2.721$ $\times 1 / 1000=\mu \mathrm{mol} / \mathrm{l}$; progesterone: $\mu \mathrm{g} / \mathrm{l} \times 3.18=\mathrm{nmol} / \mathrm{l} ; \Delta 4$ androstenedione: $\mu \mathrm{g} / \mathrm{l} \times 3.49=\mathrm{nmol} / \mathrm{l}$; testosterone: $\mu \mathrm{g} / \mathrm{l} \times 3.467=\mathrm{nmol} / \mathrm{l}$; estradiol: $\mathrm{ng} / \mathrm{l}$

$\times 3.671=\mathrm{pmol} / \mathrm{I}$. IEA, immunoenzymatic assay; $\mathrm{AMH}$, anti-Mullerian hormone.

aln early follicular phase in premenopausal women ( $<35$ years).

${ }^{b}$ Below the limit of detection of the assay.

${ }^{\mathrm{c}}$ Nadir and peak during LH pulsatility study.

\section{DNA sequencing and analysis}

The propositus and her parents gave their informed consent for genetics analysis (French bioethics law no. 2004-800). Genomic DNA was extracted from white blood cells using standard procedures. The regions spanning exon 2 and exon 3 encoding the FSH $\beta$ subunit protein were amplified by PCR with primers described in (Supplementary data, Table 1S, see section on supplementary data given at the end of this article). A negative control, containing all reagents except DNA, was included in each PCR. PCR products were sequenced using the GenomeLab Dye Terminator Cycle Sequencing Kit (DTCS, Beckman Coulter, Rassy, France) and analyzed on the CEQ 8000 Genetic Analysis System (Beckman Coulter). In addition, to perform restriction fragment length analysis in the kindred, PCR products were digested with MscI (New England BioLabs, Ozyme, France) as recommended by the manufacturer, and the products were resolved on $1.5 \%$ agarose gel electrophoresis.

\section{Preparation of expression plasmids}

The common $\alpha$ plasmid, PM2 $\alpha$ FSH $\beta$ (Supplementary Figure 1S, see section on supplementary data given at the end of this article), was kindly provided by Dr Jeffrey Weiss (Northwestern University, Chicago, IL, USA). Human FSH $\beta$ plasmid, PKR8 (Supplementary Figure 1S), was kindly provided by Dr James A Dias (Wadsworth Center for Laboratories and Research, Albany, NY, USA). Both the plasmids harbored the neomycin resistance gene.

Oligonucleotide-mediated site-directed mutagenesis was performed to create the deletion detected in the mutated FSH $\beta$ using the QuikChangeII Site-Directed
Mutagenesis Kit (Stratagene, Cambridge, UK), following instructions of the manufacturer. Clones selected by ampicillin were directly sequenced to determine that they contained the correct mutation. The entire sequence of each mutant cDNA was then determined. To confirm that the lack of expression of mutant FSH $\beta$ protein was due to the specific mutation, the mutated FSH $\beta$ plasmid was mutated back to the wild-type sequence. To exclude the possibility that the mutant FSH was not recognized by our monoclonal FSH antibody, a FLAG tag was inserted in-frame into the $\mathrm{C}$-terminal coding sequence just before the natural stop codon of wild-type $F S H \beta$ and a premature stop codon to the mutant $F S H \beta$. The insertion of polypeptides at the C-termini of human glycoprotein hormone $\beta$-subunits does not affect the $\alpha / \beta$ heterodimerization (25). Direct sequencing was carried out to confirm fidelity of the recombined sequences.

\section{Cell culture and transfection}

Chinese hamster ovary (CHO) cells were obtained from the American Type Culture Collection and grown in DMEM with F12 nutrient mixture (Invitrogen) supplemented with $10 \%$ fetal bovine serum. CHO cells were transiently cotransfected with the pM2 $\alpha$-subunit plasmid and the mutant or wild-type $F S H \beta$ construct using Lipofectamine 2000 (Invitrogen). RNA was extracted and subjected to RT-PCR for FSH $\beta$ and $\alpha$-subunit mRNA to confirm successful transfection, using appropriate negative controls (tubes without reverse transcriptase). Cellular media was collected $48 \mathrm{~h}$ after transfection and stored at $-20{ }^{\circ} \mathrm{C}$ before FSH immunoassay and bioassay. Cell lysates were also collected after $48 \mathrm{~h}$ of transfection and stored at $-20{ }^{\circ} \mathrm{C}$ for western blots.

\section{Homologous FSH in vitro bioassay}

Immortalized murine granulosa (KK-1) cells (26) stably transfected with the human FSH receptor (KK-1-hFSHR cells) were grown in DMEM with Ham's F12 nutrient mixture (Sigma) supplemented with 10\% fetal bovine serum, $200 \mathrm{mM} \mathrm{L}$-glutamine and $300 \mathrm{~g} / \mathrm{l}$ of geneticin. The KK-1-hFSHR cells were cotransfected with a cAMPresponsive luciferase reporter gene and a Renilla luciferase reporter plasmid. Forty-eight hours after transfection, the cells were treated with diluted FSH standards (WHO71/223) or samples $(100 \mu \mathrm{l}$ of cellconditioned medium from wild-type or mutant FSH producing cell lines) for $4.5 \mathrm{~h}$ at $37^{\circ} \mathrm{C}$. The medium was removed after incubation, and the cells were subjected to the luciferase reporter assay (Luminescence reporter gene assay system, PerkinElmer), by adding $100 \mu \mathrm{l}$ of assay buffer, shaking in darkness for $10 \mathrm{~min}$, and measuring luciferase activity using a luminometer (PerkinElmerWallac Victor, Turku, Finland). Thereafter, $50 \mu \mathrm{l}$ of Renilla mix ( $5 \mathrm{ml} 0.5 \mathrm{M}$ HEPES, $400 \mu \mathrm{l} 0.5 \mathrm{M}$ EDTA, 
$10 \mu \mathrm{l}$ coelenterazine dissolved in $1 \mathrm{mg} / \mathrm{ml}$ of methanol) was added to the cells, kept in darkness for $10 \mathrm{~min}$, and measured for luciferase activity in the luminometer. The luciferase/Renilla ratio was used as read-out in the FSH bioassay. The limit of detection was $3.3 \mathrm{IU} / \mathrm{l}$.

\section{Immunoassay}

Cell-conditioned medium was assayed for immunoreactive FSH using a two-site sandwich assay (Abbott Diagnostics) with a limit of detection of $0.5 \mathrm{IU} / \mathrm{l}$.

\section{Western blot}

Whole cell protein extracts were prepared in lysis buffer (50 mM HEPES (pH 7.5-7.9), $5 \mathrm{mM}$ EDTA, $150 \mathrm{mM}$ $\mathrm{NaCl}, 1 \%$ Nonidet P-40, and protease inhibitor mix (Complete protease inhibitor tablets, Roche Applied Science)). Protein concentration was determined with a protein assay kit (Bio-Rad Laboratories). Selected samples were treated with a $10 \mu \mathrm{M}$ concentration of the proteasome inhibitor MG-132 for $3 \mathrm{~h}$ before harvesting. For western blot analysis, $30 \mu \mathrm{g}$ protein were resolved on $4-12 \%$ gradient gels (NuPAGE Bis-Tris SDS9 gels (Invitrogen)) under denaturing conditions and transferred to PVDF blotting membrane (Invitrogen). The membrane was blocked with $5 \%$ milk in TBST $(50 \mathrm{mM}$ Tris (pH 7.6), $100 \mathrm{mM} \mathrm{NaCl}, 0.1 \%$ Tween 20) for $1 \mathrm{~h}$, incubated with monoclonal anti-FSH $\beta$ antibody 46.3h6.b7 produced in mouse (recognizing the regions demarcated by amino acids 33-53, 49-67, and 66-85 of the $\beta$-subunit, kindly provided by Dr James A Dias), monoclonal anti- $\beta$-actin antibody produced in mouse (Abcam, Cambridge, UK), or polyclonal anti-FLAG antibody produced in rabbit (Sigma) overnight, followed by washing three times with TBST for $5 \mathrm{~min}$. The membrane was then incubated with the second antibody, i.e. a HRP-conjugated goat anti-mouse antibody or a goat anti-rabbit antibody (1:2000 dilution; DAKO, Cambridgeshire, UK) for $1.5 \mathrm{~h}$ and detected with ECL reagent (Amersham) after three final washes with TBST for $5 \mathrm{~min}$. Finally, the membranes were exposed to X-ray film (GE Healthcare, Cambridge, UK).

\section{Ovarian stimulation with rhFSH}

Informed consent was obtained from the patient before rhFSH treatment that was requested by the patient in order to assess her fertility potential. The study was approved by the institutional review boards at Bicêtre Hospital/Paris Sud 11 University.

rhFSH (GONAL-f, Laboratoires Merck-Serono) was administered in a daily dose of 150 IU s.c. $(20,27-29)$ for 5 days, followed by $75 \mathrm{IU} /$ day for the subsequent 10 days. The patient did not receive any exogenous human chorionic gonadotropin. The medication was discontinued according to protocol criteria, because several ovarian follicles were found to exceed the diameter of $25 \mathrm{~mm}$ on day 15. Blood samples were drawn, and transabdominal pelvic and endovaginal pelvic sonography were performed basally on every 5 days during the rhFSH treatment. Pelvic sonography was also performed on 3, 10, and 20 days after discontinuation of the treatment in order to monitor ovarian and follicle sizes. Menses occurred 10 days after interruption of the rhFSH treatment, and a supplementary blood sample was obtained at that time.

\section{Results}

\section{Molecular and functional studies}

FSH $\beta$ mutation Sequencing of exon 3 of $F S H \beta$ revealed a homozygous $1 \mathrm{bp}$ (G) deletion at codon 79 (c.289delG) (Fig. 1B). This mutation produces a frameshift at codon 79 (A79fs108X), altering the C-terminal FSH $\beta$ subunit amino acid sequence 79-108 and introducing a premature stop codon at position 109. Both parents were heterozygous for the mutation. The deletion eliminates a MscI restriction site. Digestion of the PCR-amplified fragment of normal exon 3 (390 bp in size) with MscI produces two bands of 140 and 250 bp size (Fig. 1C, control). As expected, the PCR product was not digested in the proband (Fig. 1C, individual II.1). We observed three bands after digestion of the PCR products of the mother (Fig. 1C, individual I.1) and the father (Fig. 1C, individual I.2), according to the heterozygous status for the mutation. The frameshift mutation was not found in 200 chromosomes from eugonadic Caucasian controls.

Immunological and biological activities of the mutated FSH Both the wild-type and mutant FSH $\beta$ cDNAs were cotransfected with the pM2 $\alpha$ plasmid. Similar levels of mRNAs encoding the $\alpha$ - and $\beta$-subunits were confirmed in the cells expressing the wild-type or mutant FSH $\beta$ by RT-PCR (data not shown). Wild-type FSH was readily detectable in culture medium by immunoassay, whereas no mutant FSH protein was detectable ( $<0.5 \mathrm{IU} / \mathrm{l}$; Fig. 2A). In bioassays of culture medium with cells expressing the human FSH receptor, wild-type FSH was detected, but mutant FSH was undetectable ( $<3.3$ IU/l; Fig. 2B).

Western blot analysis of the mutated FSH $\beta$ subunit We investigated the consequence of the mutation for FSH $\beta$ protein expression by carrying out western blots on transfected CHO cell lysates. Wild-type $F S H \beta$ and rhFSH were detected as expected (Fig. 2C). However, mutant FSH $\beta$ could not be detected, even following treatment with the proteasome inhibitor MG-132 (Fig. 2C). To confirm that the lack of the mutated FSH $\beta$ protein was due to the specific mutation, we mutated the construct back to wild-type $F S H \beta$. Western blot analysis showed the same band in cells transfected with the back-mutated plasmid as in cells transfected 

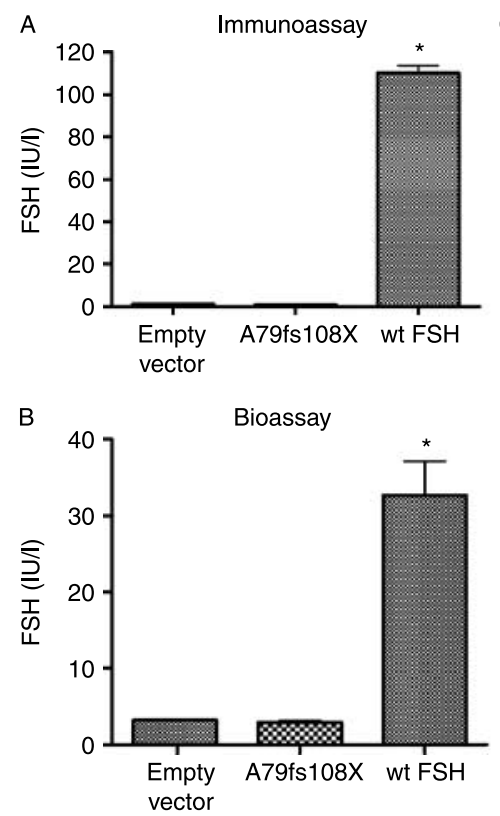

C

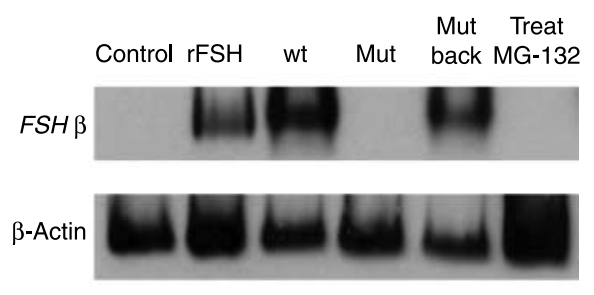

D

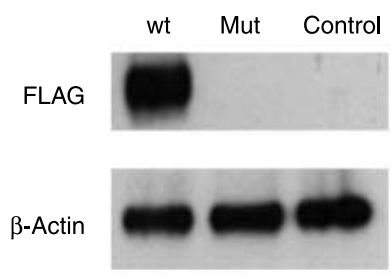

Figure 2 In vitro studies of mutated $F S H \beta$. (A) Immunoassay of FSH produced by $\mathrm{CHO}$ cells coexpressing mutated (A79fs $108 \mathrm{X}$ ) and wildtype (wt) $F S H \beta$ with $\alpha$-subunit. Cells transfected with empty vector were used as negative control. (B) In vitro bioassay of $\mathrm{FSH}$ produced by $\mathrm{CHO}$ cells coexpressing mutated (A79fs108X) and wild-type (wt) FSH $\beta$ with $\alpha$-subunit. Cells transfected with empty vector were used as negative control. (C) Lack of FSH $\beta$ protein expression in cells transfected with A79fs108X mutation of $F S H \beta$. Western blot analysis was performed on cell lysates of $\mathrm{CHO}$ cells transfected with the $\alpha$-subunit and either wild-type or mutant $F S H \beta$ plasmids. Equal amounts of protein were loaded, and an anti- $\beta$-actin antibody was used as the loading control. The FSH $\beta$ MAB $46.3 \mathrm{~h} 6 . \mathrm{b} 7$ detected a specific band corresponding to $F S H \beta$ subunit in rhFSH, wild-type, and the back-mutated $F S H \beta$, but not in mock-transfected control, mutant, or mutant treated with MG-132. (D) Cells transfected with $\alpha$-subunit and either wild-type or mutant FLAG-tagged FSH $\beta$ plasmids. Immunodetection with an anti-FLAG antibody reveals a band of the expected size (about $18 \mathrm{kDa}$ ) for the $F S H \beta$ subunit in wild-type, but not in the mutant or mock-transfected control.

with wild-type $F S H \beta$ (Fig. 2C). To exclude the possibility that mutant FSH $\beta$ was expressed but not recognized by our monoclonal FSH antibody, a FLAG tag was inserted in-frame into the $\mathrm{C}$-terminal coding sequence just before the natural stop codon of wild-type $F S H \beta$ and the premature stop codon of mutant $F S H \beta$. Immunodetection with an anti-FLAG antibody showed a band of the expected size (about $18 \mathrm{kDa}$ ) for the wild-type FSH $\beta$ subunit, but not in the mutant or mock-transfected control cells (Fig. 2D). These western blot assays showed that the mutation A79fs $108 \mathrm{X}$ failed to produce detectable FSH $\beta$ protein expression.

\section{Patient response to rhFSH administration}

Hormonal response of the ovaries Baseline gonadotropin and $\mathrm{E}_{2}$ levels before rhFSH administration confirmed isolated FSH deficiency of the woman, with undetectable serum FSH and high LH levels (Tables 1 and 2 and Fig. 3). A rise in serum FSH levels was observed during rhFSH administration with a maximum concentration of $11.5 \mathrm{IU} / \mathrm{l}$, slightly above the upper limit normal range, on day 5 . The initial increase was followed by a gradual decrease in keeping with the decreased daily dose of rhFSH administered during the

Table 2 Patient's hormonal and endometrial response to recombinant human FSH.

\begin{tabular}{|c|c|c|c|c|c|}
\hline & Basal (D0) & D5 & D10 & D15 & Normal range $\mathrm{e}^{\mathrm{a}}$ \\
\hline FSH IRMA (IU/I) & $<0.05^{b}$ & 11.5 & 8.0 & 2.5 & $3.2-8$ \\
\hline LH (IU/I) & 47 & 17.5 & 38.5 & 5.5 & $2.8-6.9$ \\
\hline Estradiol (ng/l) & 7 & 94 & 416 & 1760 & $28-76$ \\
\hline Progesterone $(\mu \mathrm{g} / \mathrm{l})$ & $<0.4$ & $<0.4$ & 4.5 & 68 & $<0.4$ \\
\hline Inhibin B (ng/l) & $<10^{\mathrm{b}}$ & 276 & 198 & 67 & $60-125$ \\
\hline Inhibin A (ng/l) & $<10^{\mathrm{b}}$ & $<10$ & 12 & 152 & $<10$ \\
\hline AMH $(\mathrm{pmol} / \mathrm{l})$ & 26 & 5.2 & 9 & 16 & $5-52$ \\
\hline Endometrial thickness (mm) & 2 & 5 & 6 & 8 & - \\
\hline
\end{tabular}

Conversion to SI units: progesterone: $\mu \mathrm{g} / \mathrm{I} \times 3.18=\mathrm{nmol} / \mathrm{l}$; estradiol: $\mathrm{ng} / \mathrm{l} \times 3.671=\mathrm{pmol} / \mathrm{l} ; \mathrm{AMH}$, anti-Mullerian hormone; ND, not determined; $\mathrm{D}$, day.

In early follicular phase in premenopausal women ( $<35$ years).

${ }^{b}$ Below the limit of detection of the assay. 
A

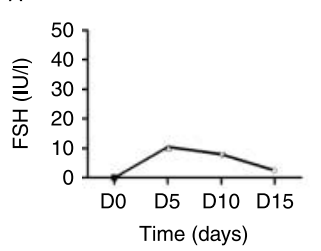

D

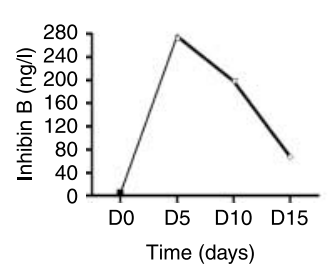

B

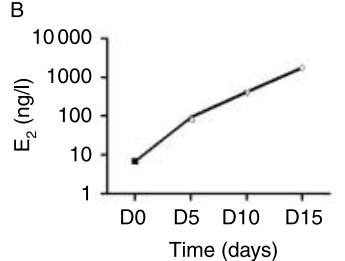

E

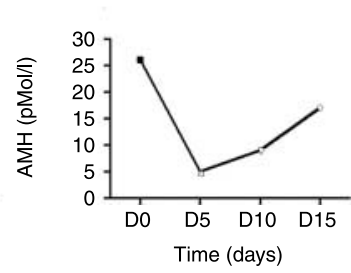

C
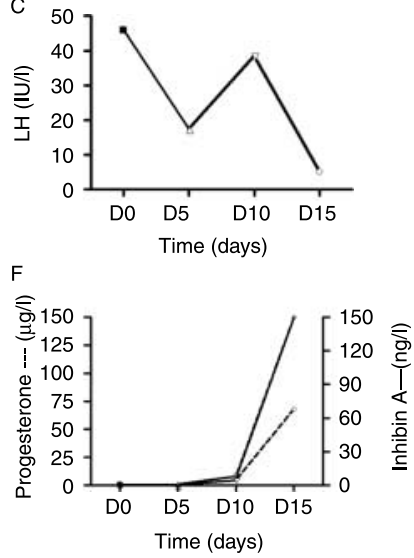

Figure 3 Circulating gonadotropin levels and ovarian hormonal responses during rhFSH administration to the patient (see text). (A) FSH, (B) estradiol (note the log scale of the $Y$ axis), (C) LH, (D) inhibin $B$, (E) anti-Mullerian hormone (AMH), (F) progesterone and inhibin $\mathrm{A}$. last 10 days of treatment (Fig. $3 \mathrm{~A}$ and Table 2). FSH fell below the limit of detection $(<0.05$ IU/l) 2 weeks after discontinuation of the treatment. The barely detectable basal level of plasma $E_{2}(7 \mathrm{ng} / \mathrm{l})$ showed a progressive but dramatic increase to a maximum of $1760 \mathrm{ng} / \mathrm{l}$ on day 15 (day of maximum follicular size; Fig. 3B and Table 2). $\mathrm{E}_{2}$ progressively decrease after discontinuing rhFSH and returned to undetectable levels $(<5 \mathrm{ng} / \mathrm{l})$ 7 days after the onset of menses.

The high basal concentration of serum LH (47 IU/l) dramatically decreased on day 5 of rhFSH treatment to $17.5 \mathrm{IU} / \mathrm{l}$ followed by an increase on day 10 (38.5 IU/l) and another decrease on day 15 to $5.5 \mathrm{IU} / \mathrm{l}$ (Fig. 3C and Table 2).

A rapid and dramatic increase in serum inhibin $B$ from undetectable basal $(<10 \mathrm{ng} / \mathrm{l})$ levels to $276 \mathrm{ng} / \mathrm{l}$ occurred after 5 days of rhFSH administration (Fig. 3D and Table 2). Interestingly, at the same time, serum AMH levels decreased (from $26 \mathrm{ng} / \mathrm{l}$ to a nadir of $5.2 \mathrm{ng} / \mathrm{l})$, followed by an increase on days 10 and 15 (Fig. 3E and Table 2). Serum AMH levels returned progressively to high pre-therapeutic levels 1 month later $(29 \mathrm{ng} / \mathrm{l})$.
During rhFSH treatment, plasma progesterone concentration increased from undetectable $(<0.1 \mu \mathrm{g} / \mathrm{l})$ to $68 \mu \mathrm{g} / \mathrm{l}$ and serum inhibin A from undetectable $(<10 \mathrm{ng} / \mathrm{l})$ to an unphysiological high of $152 \mathrm{ng} / \mathrm{l}$ on day 15 , indicating the appearance of a multiovulation (Fig. 3F and Table 2). These two ovarian hormones returned to undetectable levels 7 days after the onset of menses (not shown).

\section{Morphological ovarian and endometrial response}

Ovarian sonography before rhFSH administration showed small ovaries $(1.0$ and $1.1 \mathrm{ml}$ right and left respectively) with less than five follicles of a size below $3 \mathrm{~mm}$ in each (Figs 4A and 5). rhFSH administration induced an increase in ovarian size and a multifollicular development. After 5 days of treatment, the mean ovarian volume was $4.8 \mathrm{ml}$, and six and five follicles (sizes between 4 and $7 \mathrm{~mm}$ ) were observed in the left and right ovary respectively (Figs 4B and 5). On day 10, a further increase in follicles size occurred reaching a diameter ranging between 7 and $18.3 \mathrm{~mm}$
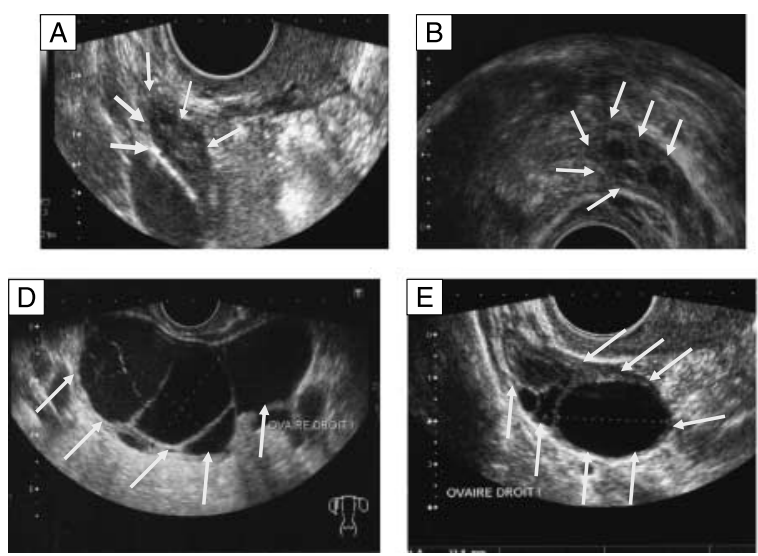

Figure 4 Effect of rhFSH administration on ovarian morphology assessed by transvaginal ultrasound. Ovarian sonography before rhFSH administration (A). After 5 days of rhFSH treatment (B). On day 10 (C), on day 15 (D) and after discontinuation of the treatment $(E)$. The ovarian aspects returned to pretherapeutic state, 2 months after discontinuation of rhFSH (F). The left ovary (not shown) was similar to the right. 


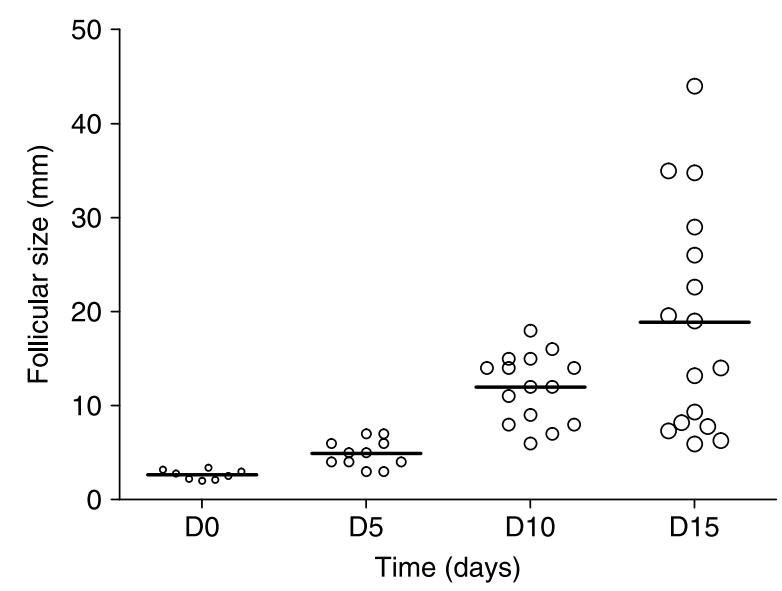

Figure 5 Diameters $(\mathrm{mm})$ of separate follicles as determined by vaginal sonography for both ovaries, before (D0) and during $\mathrm{rhFSH}$ treatment (see also text in Results section).

(Figs 4C and 5). Hyperstimulation syndrome with macrocysts appeared on day 15 (Figs 4D and 5), decreasing gradually after discontinuation of the treatment (Fig. 4E). The ovarian aspects returned to pre-therapeutic state, 2 months after discontinuation of rhFSH (Fig. 4F). Endometrial thickness increased by $6 \mathrm{~mm}$ during the treatment period (from 2 to $8 \mathrm{~mm}$; Table 2).

\section{Discussion}

Normal pubertal development depends on normal secretory patterns of FSH and LH. The functions of FSH include the stimulation of follicular development and $E_{2}$ production in females and the regulation of Sertoli cell action and spermatogenesis in males. Both inactivating mutations of FSH $\beta$ and FSHR in humans $(16,17)$, as well as in knockout mice for the same genes (30-32) have shown that FSH is essential for normal puberty and fertility in females, particularly ovarian follicular development beyond the antral stage. In males, FSH is necessary for qualitatively and quantitatively normal spermatogenesis.

The proband with the novel A79fs108X FSH $\beta$ mutation presented with clinical and laboratory evidence for severe estrogen deficiency. Her serum LH concentration was appropriately increased, indicating normal maturation of the hypothalamic-pituitarygonadal axis and an absent negative feedback. The clinical features of the proband reported here are similar to other females with genetically confirmed isolated FSH or FSHR deficiency $(8,10,11,16-19)$. Previously described females with FSH $\beta$ mutations (one homozygote for Val61X, one compound heterozygote Val61X/Cys51Gly, and three homozygotes for Tyr76X) all showed primary amenorrhea, infertility, partial pubarche, and complete or partial lack of breast development $(8,10,11,16-19)$. The laboratory findings of these patients also showed similar findings with undetectable FSH, low estrogen, and elevated LH. The association of normal androgen levels, low ovarian volume, and presumed low antral follicular sizes in this woman displaying chronically high LH levels is quite remarkable (33) and in agreement with a previous report (34). It emphasizes the crucial role of FSH to achieve the last stages in follicular development necessary for the acquisition of $\mathrm{LH}$ receptors and ovarian LH responsiveness, as well as the steroidogenic enzymes involved in androgen synthesis by the theca cells (33).

The heterozygous parents in the proband were fertile, which is consistent with other previous reported heterozygous carriers of FSH $\beta$ and FSHR mutations and in line with a disorder transmitted as an autosomal recessive trait.

In vitro analysis of the A79fs $108 \mathrm{X}$ mutation demonstrated undetectable FSH by both immunoassay and in vitro bioassay, which is similar to previous reports on FSH $\beta$ mutations $(10,11)$. The 1 bp deletion in codon 79 caused a frameshift that completely altered amino acids 79-108 and leads to a premature stop codon in codon 109 , and amino acids 109-111 not being translated. According to the crystal structure of FSH $\beta$ (35), FSH resembles structurally members of the cystine knot growth factor family $(36,37)$. The $\beta$-hairpins of the molecule are stabilized and associated through six important disulfide bridges, and the cystine knot composed of $\beta 32-84, \beta 28-82$, and $\beta 3-51$ is the central motif (35). The heterodimer is apparently stabilized by a 'seatbelt' structure formed by the disulfide $\beta 20-104$ wrapping around the $\alpha$-subunit $(16,25,38,39)$. The current mutant, altering amino acids 79-108, disrupts four disulfide bond pairings of hFSH, including $\beta 20-104, \beta 32-84, \beta 28-82$, and $\beta 87-94$, which may cause alteration of the cystine knot and seatbelt configurations. The cystine knot is critical for maximal intracellular stability of the subunit and for mutual recognition and subsequent interaction of the subunits (38). The mutant FSH $\beta$ protein could not be detected in the cell lysates suggesting that it is unstable and degrades rapidly. This result is consistent with another study, which demonstrated that a mutation deleting the $\beta 28-82$ disulfide bond, and disrupting the cystine knot, also resulted in undetectable $F S H \beta$ (38). The $\beta 20-104$ disulfide bond disrupted by the current mutation would also interfere with dimer formation. Because free undimerized $F S H \beta$ are very unstable $(8,40)$, defective dimerization is likely to account in part for the defective synthesis and subsequent secretion of the mutant FSH. Moreover, the sequence between $\beta 93$ and $\beta 99$ is known to belong to the FSH receptor-binding site $(41,42)$, which is also disrupted by this mutation. Together, the above observations suggest that the A79fs108X mutant of $F S H \beta$ can be predicted to be unstable, unable to be associated with the $\alpha$-subunit, unable to be secreted, 
and unable to bind to FSH receptor, leading to failure of intact hormone secretion and action. In accordance, our findings showed absence of bioassayable FSH and no FSH immunoreactivity in cells expressing the mutant $F S H \beta$.

In sharp contrast to the previously reported women with combined FSH and LH deficiency (20, 27-29), we show here in response to rhFSH the development of multiple follicles observed by transvaginal sonography that emerged together with a marked rise in $E_{2}$ and a significant increase in endometrial thickness. This indicated that in response to rhFSH, the high spontaneous LH levels are the prerequisite to allow adequate thecal androstenedione synthesis to provide substrate for the FSH-induced aromatase activity in granulosa cells, leading together to substantial $\mathrm{E}_{2}$ secretion.

Another interesting characteristic in the hormone profile of the woman described here was the undetectable serum inhibin B level associated with normal serum AMH level. It suggests that ovarian inhibin B secretion in humans is mainly FSH-dependent, whereas normal AMH secretion can occur even in the absence of this gonadotropin. Furthermore, we observed a decrease in serum AMH levels in response to rhFSH. This response, also reported in women with polycystic ovarian disease receiving rhFSH (43), could be related to the in vivo and in vitro data showing that FSH treatment significantly reduces AMH levels in follicular fluid and expression in cultured granulosa cells (44).

Finally, a conspicuous finding was the exaggerated ovarian response to rhFSH in the patient, although the rhFSH doses used were the same as usually administrated to female patients displaying gonadotropin deficiency $(20,27-29)$. The iatrogenic ovarian multifollicular hyperstimulation could therefore be related to the high spontaneous circulating pretherapeutic LH levels which could potentiate in a deleterious way the FSH induced follicular growth (45). Further work is necessary to demonstrate if a decrease in LH levels by GnRH analogs before rhFSH administration could prevent the exaggerated ovarian response in women with isolated FSH deficiency.

\section{Supplementary data}

This is linked to the online version of the paper at http://dx.doi.org/ 10.1530/EJE-09-0648.

\section{Declaration of interest}

The authors declare that there is no conflict of interest that could be perceived as prejudicing the impartiality of the research reported.

\section{Funding}

This work was supported in part by grant from Université Paris Sud 11 (BQR 2009).

\section{References}

1 Bouligand J, Ghervan C, Tello JA, Brailly-Tabard S, Salenave S, Chanson P, Lombes M, Millar RP, Guiochon-Mantel A \& Young J. Isolated familial hypogonadotropic hypogonadism and a GNRH1 mutation. New England Journal of Medicine $20093602742-2748$.

2 Chan YM, de Guillebon A, Lang-Muritano M, Plummer L, Cerrato F, Tsiaras S, Gaspert A, Lavoie HB, Wu CH, Crowley WF Jr, Amory JK, Pitteloud N \& Seminara SB. GNRH1 mutations in patients with idiopathic hypogonadotropic hypogonadism. PNAS 2009106 11703-11708.

3 de Roux N, Young J, Misrahi M, Genet R, Chanson P, Schaison G \& Milgrom E. A family with hypogonadotropic hypogonadism and mutations in the gonadotropin-releasing hormone receptor. New England Journal of Medicine 1997337 1597-1602.

4 Layman LC, Cohen DP, Jin M, Xie J, Li Z, Reindollar RH, Bolbolan S, Bick DP, Sherins RR, Duck LW, Musgrove LC, Sellers JC \& Neill JD. Mutations in gonadotropin-releasing hormone receptor gene cause hypogonadotropic hypogonadism. Nature Genetics 1998 18 14-15.

5 de Roux N, Genin E, Carel JC, Matsuda F, Chaussain JL \& Milgrom E. Hypogonadotropic hypogonadism due to loss of function of the KiSS1-derived peptide receptor GPR54. PNAS $200310010972-10976$.

6 Seminara SB, Messager S, Chatzidaki EE, Thresher RR, Acierno JS Jr, Shagoury JK, Bo-Abbas Y, Kuohung W, Schwinof KM, Hendrick AG, Zahn D, Dixon J, Kaiser UB, Slaugenhaupt SA, Gusella JF, O'Rahilly S, Carlton MB, Crowley WF Jr, Aparicio SA \& Colledge WH. The GPR 54 gene as a regulator of puberty. New England Journal of Medicine 2003349 1614-1627.

7 Topaloglu AK, Reimann F, Guclu M, Yalin AS, Kotan LD, Porter KM, Serin A, Mungan NO, Cook JR, Ozbek MN, Imamoglu S, Akalin NS, Yuksel B, O'Rahilly S \& Semple RK. TAC3 and TACR3 mutations in familial hypogonadotropic hypogonadism reveal a key role for Neurokinin B in the central control of reproduction. Nature Genetics 200941 354-358.

8 Matthews $\mathrm{CH}$, Borgato S, Beck-Peccoz P, Adams M, Tone Y, Gambino G, Casagrande S, Tedeschini G, Benedetti A \& Chatterjee VK. Primary amenorrhoea and infertility due to a mutation in the beta-subunit of follicle-stimulating hormone. Nature Genetics 19935 83-86.

9 Weiss J, Axelrod L, Whitcomb RW, Harris PE, Crowley WF \& Jameson JL. Hypogonadism caused by a single amino acid substitution in the beta subunit of luteinizing hormone. New England Journal of Medicine 1992326 179-183.

10 Layman LC, Lee EJ, Peak DB, Namnoum AB, Vu KV, van Lingen BL, Gray MR, McDonough PG, Reindollar RH \& Jameson JL. Delayed puberty and hypogonadism caused by mutations in the folliclestimulating hormone beta-subunit gene. New England Journal of Medicine 1997337 607-611.

11 Layman LC, Porto AL, Xie J, da Motta LA, da Motta LD, Weiser W \& Sluss PM. FSH beta gene mutations in a female with partial breast development and a male sibling with normal puberty and azoospermia. Journal of Clinical Endocrinology and Metabolism $2002873702-3707$.

12 Dode C, Levilliers J, Dupont JM, De Paepe A, Le Du N, SoussiYanicostas N, Coimbra RS, Delmaghani S, Compain-Nouaille S, Baverel F, Pecheux C, Le Tessier D, Cruaud C, Delpech M, Speleman F, Vermeulen S, Amalfitano A, Bachelot Y, Bouchard P, Cabrol S, Carel JC, Delemarre-van de Waal H, Goulet-Salmon B, Kottler ML, Richard O, Sanchez-Franco F, Saura R, Young J, Petit C \& Hardelin JP. Loss-of-function mutations in FGFR 1 cause autosomal dominant Kallmann syndrome. Nature Genetics $200333463-465$.

13 Dode C, Teixeira L, Levilliers J, Fouveaut C, Bouchard P, Kottler ML, Lespinasse J, Lienhardt-Roussie A, Mathieu M, Moerman A, Morgan G, Murat A, Toublanc JE, Wolczynski S, Delpech M, Petit C, Young J \& Hardelin JP. Kallmann syndrome: mutations in the genes encoding prokineticin-2 and prokineticin receptor-2. PLoS Genetics 20062 e175. 
14 Kim HG, Kurth I, Lan F, Meliciani I, Wenzel W, Eom SH, Kang GB, Rosenberger G, Tekin M, Ozata M, Bick DP, Sherins RJ, Walker SL, Shi Y, Gusella JF \& Layman LC. Mutations in CHD7, encoding a chromatin-remodeling protein, cause idiopathic hypogonadotropic hypogonadism and Kallmann syndrome. American Journal of Human Genetics 200883 511-519.

15 Jongmans MC, van Ravenswaaij-Arts CM, Pitteloud N, Ogata T, Sato N, Claahsen-van der Grinten HL, van der Donk K, Seminara S, Bergman JE, Brunner HG, Crowley WF Jr \& Hoefsloot LH. CHD7 mutations in patients initially diagnosed with Kallmann syndrome - the clinical overlap with CHARGE syndrome. Clinical Genetics 200975 65-71.

16 Layman LC \& McDonough PG. Mutations of follicle stimulating hormone-beta and its receptor in human and mouse: genotype/ phenotype. Molecular and Cellular Endocrinology 2000 161 9-17.

17 Themmen APN \& Huhtaniemi IT. Mutations of gonadotropins and gonadotropin receptors: elucidating the physiology and pathophysiology of pituitary-gonadal function. Endocrine Reviews 2000 21 551-583.

18 Berger K, Souza H, Brito VN, d'Alva CB, Mendonca BB \& Latronico AC. Clinical and hormonal features of selective folliclestimulating hormone (FSH) deficiency due to FSH beta-subunit gene mutations in both sexes. Fertility and Sterility 200583 466-470.

19 Lofrano-Porto A, Casulari LA, Nascimento PP, Giacomini L, Naves LA, da Motta LD \& Layman LC. Effects of follicle-stimulating hormone and human chorionic gonadotropin on gonadal steroidogenesis in two siblings with a follicle-stimulating hormone beta subunit mutation. Fertility and Sterility 200890 1169-1174.

20 Couzinet B, Lestrat N, Brailly S, Forest M \& Schaison G. Stimulation of ovarian follicular maturation with pure folliclestimulating hormone in women with gonadotropin deficiency. Journal of Clinical Endocrinology and Metabolism $1988 \mathbf{6 6}$ $552-556$.

21 Couzinet B, Young J, Kujas M, Meduri G, Brailly S, Thomas JL, Chanson P \& Schaison G. The antigonadotropic activity of a 19-nor-progesterone derivative is exerted both at the hypothalamic and pituitary levels in women. Journal of Clinical Endocrinology and Metabolism $1999 \mathbf{8 4} 4191-4196$.

22 Boukari K, Meduri G, Brailly-Tabard S, Guibourdenche J, Ciampi ML, Massin N, Martinerie L, Picard JY, Rey R, Lombes M \& Young J. Lack of androgen receptor expression in Sertoli cells accounts for the absence of anti-Mullerian hormone repression during early human testis development. Journal of Clinical Endocrinology and Metabolism 200994 1818-1825.

23 Bry-Gauillard H, Meduri G, Abirached F, Constancis E, Brailly S, Chanson P \& Young J. Primary amenorrhea revealing an occult progesterone-secreting ovarian tumor. Fertility and Sterility 2008 901198 e1191-e1195.

24 Bergada I, Ballerini GM, Ayuso S, Groome NP, Bergada C \& Campo S. High serum concentrations of dimeric inhibins A and B in normal newborn girls. Fertility and Sterility 200277 363-365.

25 Garcia-Campayo V \& Boime I. Novel recombinant gonadotropins. Trends in Endocrinology and Metabolism 200112 72-77.

26 Kananen K, Markkula M, Rainio E, Su JG, Hsueh AJ \& Huhtaniemi IT. Gonadal tumorigenesis in transgenic mice bearing the mouse inhibin alpha-subunit promoter/simian virus T-antigen fusion gene: characterization of ovarian tumors and establishment of gonadotropin-responsive granulosa cell lines. Molecular Endocrinology 19959 616-627.

27 Schoot DC, Coelingh Bennink HJ, Mannaerts BM, Lamberts SW, Bouchard P \& Fauser BC. Human recombinant follicle-stimulating hormone induces growth of preovulatory follicles without concomitant increase in androgen and estrogen biosynthesis in a woman with isolated gonadotropin deficiency. Journal of Clinical Endocrinology and Metabolism 199274 1471-1473.

28 Kousta E, White DM, Piazzi A, Loumaye E \& Franks S. Successful induction ovulation and completed pregnancy using recombinant human luteinizing hormone and follicle stimulating hormone in a woman with Kallmann's syndrome. Human Reproduction 199611 70-71.
29 Recombinant human luteinizing hormone (LH) to support recombinant human follicle-stimulating hormone (FSH)-induced follicular development in LH- and FSH-deficient anovulatory women: a dose-finding study. The European Recombinant Human LH Study Group. Journal of Clinical Endocrinology and Metabolism 199883 1507-1514.

30 Huhtaniemi I. Mutations along the pituitary-gonadal axis affecting sexual maturation: novel information from transgenic and knockout mice. Molecular and Cellular Endocrinology 2006 254-255 84-90.

31 Kumar TR, Wang Y, Lu N \& Matzuk MM. Follicle stimulating hormone is required for ovarian follicle maturation but not male fertility. Nature Genetics 199715 201-204.

32 Kumar TR, Low MJ \& Matzuk MM. Genetic rescue of folliclestimulating hormone beta-deficient mice. Endocrinology 1998139 3289-3295.

33 Gougeon A. Regulation of ovarian follicular development in primates: facts and hypotheses. Endocrine Reviews $1996 \mathbf{1 7}$ $121-155$.

34 Barnes RB, Namnoum AB, Rosenfield RL \& Layman LC. The role of LH and FSH in ovarian androgen secretion and ovarian follicular development: clinical studies in a patient with isolated FSH deficiency and multicystic ovaries. Human Reproduction 200217 $88-91$.

35 Fox KM, Dias JA \& Van Roey P. Three-dimensional structure of human follicle-stimulating hormone. Molecular Endocrinology $200115378-389$.

36 Isaacs NW. Cystine knots. Current Opinion in Structural Biology 19955 391-395.

37 Sun PD \& Davies DR. The cystine-knot growth-factor superfamily. Annual Review of Biophysics and Biomolecular Structure 199524 269-291.

38 Hiro'oka T, Maassen D, Berger P \& Boime I. Disulfide bond mutations in follicle-stimulating hormone result in uncoupling of biological activity from intracellular behavior. Endocrinology 2000 141 4751-4756.

39 Lapthorn AJ, Harris DC, Littlejohn A, Lustbader JW, Canfield RE, Machin KJ, Morgan FJ \& Isaacs NW. Crystal structure of human chorionic gonadotropin. Nature 1994369 455-461.

40 Keene JL, Matzuk MM \& Boime I. Expression of recombinant human choriogonadotropin in Chinese hamster ovary glycosylation mutants. Molecular Endocrinology 19893 2011-2017.

41 Lindau-Shepard B, Roth KE \& Dias JA. Identification of amino acids in the C-terminal region of human follicle-stimulating hormone (FSH) beta-subunit involved in binding to human FSH receptor. Endocrinology 1994135 1235-1240.

42 Dias JA, Lindau-Shepard B, Hauer C \& Auger I. Human folliclestimulating hormone structure-activity relationships. Biology of Reproduction 199858 1331-1336.

43 Catteau-Jonard S, Jamin SP, Leclerc A, Gonzales J, Dewailly D \& di Clemente N. Anti-Mullerian hormone, its receptor, FSH receptor, and androgen receptor genes are overexpressed by granulosa cells from stimulated follicles in women with polycystic ovary syndrome. Journal of Clinical Endocrinology and Metabolism 2008 93 4456-4461.

44 Pellatt L, Hanna L, Brincat M, Galea R, Brain H, Whitehead S \& Mason H. Granulosa cell production of anti-Mullerian hormone is increased in polycystic ovaries. Journal of Clinical Endocrinology and Metabolism 200792 240-245.

45 Sullivan MW, Stewart-Akers A, Krasnow JS, Berga SL \& Zeleznik AJ. Ovarian responses in women to recombinant follicle-stimulating hormone and luteinizing hormone (LH): a role for LH in the final stages of follicular maturation. Journal of Clinical Endocrinology and Metabolism 199984 228-232.

Received 1 December 2009

Accepted 2 December 2009 